\title{
Chapter 8 \\ Invented Nostalgia: The Search for Identity Among the Hungarian Far-Right
}

\author{
Katherine Kondor and Mark Littler
}

\subsection{Introduction}

While nostalgia is not necessarily an aspect of all forms of nationalism, most contemporary groups share a preoccupation with the past, adopting a retrospective view of the world that harks back to a forgotten "golden age" for their nation. For some, as in the United Kingdom, this can evoke Empire and narratives of social and political dominance (Gottlieb and Linehan 2003); while in other nations nostalgic nationalism may focus on identity, and the idealization of a past in which nation-states contained only one people bound by common ethnic roots and cultural practices. The resulting diversity of organizations and ideologies that may be considered nationalist - and even nostalgic nationalist - is vast, a fact attested to by the variety of chapters in this volume. However, in the context of some groups and organizations, most notably those in Hungary, the past plays a particularly significant role in shaping political outlooks. The complexity of the Hungarian far-right is well documented, with their commemoration of several key periods in the country's history and their foregrounding of the importance of Hungary's Christian traditions and beliefs argued to set them apart from the experience in many other countries (Bartlett et al. 2012). Moreover, Hungary has a particularly broad range of groups operating within this space, with far-right organizations combining different time-periods to create and shape their own particular forms of nostalgia, framing identities in diverse ways that create a fractured and complex nationalist milieu. Alongside this,

\footnotetext{
K. Kondor $(\bowtie)$

School of Social Sciences and Humanities, Loughborough University, Loughborough, UK e-mail: k.a.kondor@lboro.ac.uk

M. Littler

Department of Behavioural and Social Sciences, University of Huddersfield, Huddersfield, UK

e-mail: m.littler@hud.ac.uk
} 
government-sponsored ideas of nostalgic nationalism contribute to a challenging, if often obfuscated, ideological landscape, supporting attitudes and ideas of the farright within the broader populous. It is against this backdrop that this chapter seeks to position its consideration of nostalgic nationalism in Hungary.

Using both an analysis of symbols and qualitative interviews to explore the role of nostalgia in shaping the ideology of members of the Hungarian Defense Movement (Magyar Önvédelmi Mozgalom), this chapter is structured in six sections. In the first, several important concepts are outlined for clarification, with a description of the methodological approach employed specified in the following paragraphs. Subsequently the attitudes and values characteristic of the Hungarian nationalist movement are discussed to provide a basis for understanding their mobilization. The fourth section provides an overview the current landscape of the major organizations in the Hungarian far-right movement alongside evidence of their use of nostalgia and the politics of national identity. The penultimate section presents empirical data from semi-structured interviews to provide a better understanding of nostalgic nationalism and the politics of national identity in Hungary. Finally, conflicts that emerge in the formation of Hungarian nationalist identity are discussed before a conclusion offering suggestions for future research and an overview of the limitations of this study.

\subsubsection{On Nostalgic Nationalism}

Nationalism can be viewed as an ideology that helps to create and maintain identity for an individual or group or create a unity between the people of one population (Smith 1995). It can be understood as an organizing political principle that places high importance on national homogenization and gives priority to national values and interests with the aim of achieving some collective goal. Moreover, it can also be seen to describe an affection toward one's nation, as crafting a sense of belonging to a particular group with a supposed common origin, and as instilling a desire to keep the nation pure (Dekker et al. 2003). Alongside this, ethno-nationalism can be seen as a further sub-genus of nationalism, viewing the nation as a community of descent whose members are related by fictive kinship ties to supposedly common ancestors, embracing myths of origin, nativist history, folk culture, and a populist political philosophy (Smith 1995, 2001). This type of nationalism is often seen in post-independence movements, irredentist movements, and "pan" nationalisms, and is a key characteristic of contemporary nationalist discourse in Hungary.

The word nostalgia has its roots in two Greek words: nostos, meaning a return home, and algos, meaning pain and longing. The meaning of the term nostalgia originally indicated a feeling of homesickness and longing for place, but over time was expanded to include a temporal aspect directed towards the past. As a result it has come to imply a special type of memory, the pain having been removed; it implies a longing for an idealized past, which does not, or never did, exist (Goulding 1999). It can be personal, or grounded in the collective memory of a larger group. It 
can even, curiously, be for a time and place that an individual or collective never experienced first-hand. When combined with nationalism, it can be defined as a longing for a heartland when the nation was still theoretically homogenous (see Hellström et al., Chap. 1, in this volume). This can create a sense of belonging and, as in the case of Hungary, the sense of identity that is so desperately sought by many in the far-right.

Nostalgic nationalism is related to ethno-nationalism in many ways, but the two are not synonymous: the former is based on the idea of fictive kinship ties and the collective memory of ethnic and national groups, as with ethno-nationalism. However, in placing its emphasis on a homogenous nation, and in looking to the past for the establishment and maintenance of identity, it differs in a key respect. Accepting this distinction this chapter will explore these ideas through the lens of various organizations that comprise the broad Hungarian far-right "movement", here taken to refer to the entire nationalist network in Hungary. It is not the goal of this chapter to discuss all organizations on the Hungarian far-right, of which there are many; rather, the focus here is to explore and map the evidence of nostalgic nationalism in the attitudes and characteristics of several key organizations.

\subsubsection{Methodology and Data Collection}

This chapter employs two distinct approaches. The first offers a discussion of the main aspects of Hungarian history in order to set a basis for further analysis and provide an overview of the characteristics of Hungarian nostalgic nationalism. The main far-right organizations in Hungary are reviewed and discussed from the perspective of nostalgic nationalism, considering how they present and embody their experience of the past, and how the past influences their outlook, attitudes, and ideology. To gain an understanding of identity this section will employ an analysis of symbols. Symbols are widely under-stood as key markers of group outlook, aiding in communication (Firth 1973) in a way which is both subjective and objective; some are always identified in the same way by different people, while others evoke emotion associated with a situation (Edelman 1985). The latter type can induce "patriotic pride, anxieties, remembrances of past glories or humiliations" (Edelman 1985, p. 6). National symbolism may thus have great political power and evoke may emotional expression of national identification, allegiance, and self-sacrifice (Schatz and Lavine 2007); it often elicits claims to a specific history and sovereignty and highlights the distinctive nature of the nation (Elgenius 2011). National symbols may also place emphasis on a nation's historical past in a way that can then be glorified, romanticized, and mythologized (Schatz and Lavine 2007). Their use far-right organizations can thus allow them to project their image to their own group members, as well as to others outside the organization, giving their ideology shape and form (Breuilly 1993). Particularly in the political context, such symbols are selected and combined to provoke emotions and to refer to specific ideas (Mach 1993). 
The second part of the chapter presents the results of a series of interviews with members of the Hungarian Defense Movement in early 2018. The transcripts of three respondents are used, with their personal data anonymized, presented as Respondent 1, 2, and respectively 3. The interviews were conducted via Skype-out call and lasted about 20-30 min each. They were conducted in Hungarian, and they were later transcribed and coded in Hungarian, with key quotes translated into English ${ }^{1}$. While this is a comparably small sample size, and is thus limited in terms of both its validity and reliability, these are to date the only scholarly interviews conducted with members of this organization, and provide an unfiltered view of the thoughts and emotions of group members.

\subsection{The Roots of Nostalgic Nationalism in Hungary}

Hungarian national identity seems to be something of a puzzle, combining veneration for ancient pagan ancestors with strong Christian beliefs. To resolve this contradiction, it is important to understand the country's turbulent history, and in particular, the important role played by external domination and occupation in shaping the national psyche. This section provides a brief overview of the country's history up to the twentieth century, as a way of offering a frame of reference for understanding nostalgic nationalism in contemporary Hungary.

One important period for Hungarian nationalism, and especially nostalgic nationalism, is the settlement of the nomadic Magyar tribes in the Carpathian basin around 895 C.E. According to historical sources the Magyars arrived in a group of seven tribes, said to be led by a chieftain named Árpád; they were originally a nomadic Asiatic people who were not Christian, but had a shamanistic system of beliefs lead by a táltos (similar to a shaman). The nomadic Magyars fashioned their facial hair in a distinctive manner, wore the dolmány (a special long coat worn by men), and a tarsoly (sabretache). Their use of spiritual flora and fauna symbolism, proficiency in archery, and the importance attached to equestrian culture are all seemingly crucial elements of Hungarian "tradition-guarding" (hagyományörzés) culture. This is widespread within the Hungarian far-right movement, and indeed in the wider population, even among those not engaged in politics. This seeming rejection of modernism may be understood as part of a belief that modernity has erased the "true" national identity of Hungary.

A key belief among those involved in Hungarian nationalism is the idea that the original Hungarians, the Magyar people, came from the East and hence have more genetic and cultural ties to Eastern people than to Europeans. This idea is known as pan-Turanism, a term that stems from the Iranian term turan referring to a region of

\footnotetext{
${ }^{1}$ The focus of the interviews was mainly the respondents' involvement in the organization: the origins of their nationalist feelings, how they became involved with the organization, and their activities in it. In addition to this information, respondents often discussed their views on the history of the Hungarian people and their ideas about Hungarian national identity.
} 
Central Asia; which may be seen as a form of Orientalism in pursuit of national identity formation. This serves to differentiate the Hungarians from their mostly Slavic neighbors in Central and Eastern Europe, and positions them as ethnically Asian. Pan-Turanism is emphasized by many who engage in Hungarian traditionguarding and has ultimately culminated in the biennial Kurultáj festival. Meaning a gathering of tribes, the event invites representatives from Uzbekistan, Kyrgyzstan, Mongolia, and many other countries. Visitors can watch horse shows, learn about Shamanism, attend lectures on the archaeology and culture of the Conquering Period, and often attend a concert by one of Hungary's nationalist rock bands, such as Kárpátia (Carpathia) and Ismerös Arcok (Familiar Faces).

As the Magyar people held onto their own spiritual beliefs, they were Christianized only at a later stage, following the creation of the Kingdom of Hungary in the year 1000. The following several centuries saw many outside cultures and invading forces enter the borders of modern Hungary. Indeed, even if the Hungarian people ever were ethnically homogenous, they were not so for long: Hungary was invaded and depopulated by the Mongols in 1241 (Engel 2001) and the Ottomans in 1526 (Simon 1998), following which waves of immigration saw people from Russia, Austria, Italy, Germany, and France. As a result, ethnic Hungarians only made up $35 \%$ of the total population in 1786 . This shift is key to understanding the contradiction of Hungarian nostalgic nationalism and the desire for Hungarian "purity".

Under the Austro-Hungarian dual monarchy, formed in 1867, Hungarian art, literature, and society flourished, enjoying a "golden age" that lasted until the end of the First World War. The founding of an Austrian federal republic in late 1918 marked the end of the Austro-Hungarian empire, with the Hungarian part of the dual monarchy dismantled and shared among its diverse populations: Hungarians, but also Slovaks, Romanians, Germans, Croats, Serbs, and Ruthenians (Molnár 2001). After the Treaty of Trianon was signed on June 4, 1920, Hungary went from a population of 18 million to a small country of just less than eight million (Hajdú and Nagy 1990). In the process, Hungary had lost about two-thirds of its territories and three-fifths of its inhabitants and was now "the most nationally aggrieved state in all of Europe" (Payne 1980, p. 110).

Indeed, denunciation of the Treaty of Trianon and anti-Habsburg sentiments are at the core of much of Hungarian far-right ideology. For many Hungarians, and especially for supporters of the far-right, the treaty of Trianon represents the splitting of the heartland; much of Hungarian nostalgic nationalism seeks to a desire to reunite this homeland, however unfeasible it may be at present. Hungary's preTrianon borders are referred to as "Greater Hungary" by nationalist supporters, with the very concept of "Greater Hungary" symbolizing the reunification of all ethnic Hungarians from once-Hungarian lands. It is also commonly represented physically by the image of present-day Hungary set within the pre-Trianon borders of the country, which often appears on decals, jewelry, and clothing. In another incarnation, it appears as a chant used by many far-right groups: "Down with Trianon!" (Vesszen Trianon!). As a result much Hungarian nationalist nostalgia ends around the time of the Treaty of Trianon, though some (often more extreme) organizations (for example, Pax Hungarica, the Hungarian Guard, and some skinhead 
organizations) have also drawn on the symbols of the Hungarian national socialism, and in particular the Arrow Cross. This is, however, relatively rare among Hungarian far-right organizations.

A few other key attitudes are prominent within the Hungarian nationalist movement. One of the central characteristics of the Hungarian far-right is its anti-Roma outlook, which is a recurring trope throughout much of Central and Eastern Europe. Indeed, the term "gypsy criminality" (cigánybünözés) was revived by Jobbik (Juhász 2010) and many do indeed believe that the Roma are biologically programmed to be criminals. In far-right ideology, the Roma are not seen as being part of the original Hungarian nation, hence ideas of nostalgic nationalism can often imply a return to a time before their arrival in Hungary ${ }^{2}$.

The far-right in Hungary, more generally, is also concerned with issues surrounding the traditional family. These ideas about traditional family are most often encompassed in the idea of "European Christian values" and ideals. While not representing ideas of nostalgia per se, they do show how far-right organizations embody an extreme Christian identity and, as discussed below, stand in contrast to the idea of the pre-Christian "true" Hungarian. These extreme "Christian" values are often translated into homophobia, which is common in the far-right movement and is also quite frequently witnessed in state-run media. For example, the staging of the musical Billy Elliot was cancelled in Budapest for promoting "gay propaganda" (Wootson 2018). In another case, the far-right Sixty-Four Counties Youth Movement attempted to disrupt the Budapest gay pride event in the summer of 2018, embedding themselves at the center of the pride parade with a large banner reading "Sin cannot be the object of pride" (HVIM 2018).

As described above, Hungary's turbulent history raises many questions about the country's ethnic and cultural "purity". There are many periods in Hungary's history that are important for understanding both national and nationalist identity, such as the time of the Hungarian conquests, the Christian Árpád dynasty, the "golden age" of Austro-Hungary, and the trauma caused by the Treaty of Trianon. The next section discusses the landscape of the Hungarian far-right movement, and the types of nostalgic nationalisms that are encountered in several key organizations.

\subsection{A Discussion of Nostalgia and the Politics of National Identity Among Hungarian Far-Right Organizations}

There can be no discussion of the far-right in Hungary without a consideration of the main Hungarian right-wing populist party: the Movement for a Better Hungary (Jobbik Magyarországért Mozgalom, Jobbik). Originally founded in 2003 with close links to the nationalist movements, and paramilitary organizations (Kyriazi

\footnotetext{
${ }^{2}$ It is unknown as to exactly when the Roma people arrived in Europe, but it is thought to be as early as the twelfth century.
} 
2015), Jobbik entered the political scene by joining forces with the anti-Semitic Hungarian Justice and Life Party (Magyar Igazság és Élet Pártja, MIÉP), and together they received $2.2 \%$ of vote in the 2006 elections. This initial difficulty notwithstanding, Jobbik's support grew over the following years, eventually rising to $14.47 \%$ of the vote in the 2010 parliamentary elections. This number increased further to $20.22 \%$ in 2014, by which time their ideology had become openly antiliberal and anti-EU, with homophobic, anti-Semitic, and anti-Roma rhetoric also growing in prominence (Bartlett et al. 2012; Holdsworth and Kondor 2017). Following the 2014 national elections, Jobbik attempted to change their image, and adopt a "softer" and more moderate tone with the party's then-leader, Gábor Vona, described his new vision for Jobbik as a "modern conservative party" (Thorpe 2016). This image change did not succeed as well as Jobbik had hoped; in the 2018 Hungarian national elections they achieved only $19.06 \%$ of the vote and 26 seats in parliament (see Loch and Norocel 2015, pp. 263-265; Cinpoeş and Norocel, Chap. 4 in this volume, for a further discussion of Jobbik). Although their electoral support was somewhat reduced, Jobbik became the second largest party in the Hungarian parliament, and the only real opposition party to the current government. However, immediately following the election, Vona kept his promise to his party: if they lost the election, he would step down. His resignation sparked a split in the party, and several members left in June 2018 to form a new radical nationalist political party named Our Homeland Movement (Mi Hazánk Mozgalom). The new party is chaired by László Toroczkai, the founder of the Sixty-Four Counties Youth Movement, who has openly expressed a desire for a "white" Hungary (ECHO TV 2018).

Alongside this, the main party of the current Hungarian far-right governmental coalition, the Alliance of Young Democrats-Hungarian Civic Alliance (Fiatal Demokraták Szövetsége-Magyar Polgári Szövetség, Fidesz), was founded in 1988 as an anti-communist party. Led by Viktor Orbán, the party has radically changed its politics since its foundation. In the past, the party has been described as a "mainstream conservative party with radical right policies" (Mudde 2015). Now, however, it has been argued in policy and media communities that Fidesz are firmly situated on the far-right (Heijmans 2019). In the period after Fidesz's election in 2010 and up until their second (consecutive term) re-election in 2014, Fidesz effectively turned Hungary into "a culture within which racist speech and prohibited far-right paramilitary activities are tolerated" (Fekete 2016, p. 40). The most striking and long lasting of their campaigns was the campaign against migrants, sparked by the migrant crisis of 2015, when images of refugee men, women, and children at the Budapest Keleti train station were used as propaganda by the government. The government also proceeded to place anti-migrant billboards around the country and flood the news media with anti-immigrant rhetoric. This anti-immigrant campaign intensified again before the 2018 elections, but suddenly softened in its aftermath. Additionally, in 2017 Fidesz began a campaign, which may be deemed anti-Semitic, against the Jewish Hungarian-American philanthropist George Soros. This has included the attempted closure, and now expulsion of the Central European University (CEU) in Budapest, and anti-Soros billboards around the country. While there is a tendency in scholarship to focus on Jobbik, as they are indeed a populist 
far-right party, Fidesz has now seemingly occupied Jobbik's space in Hungarian politics and now sets the nationalist undertones in Hungary's government and people.

Fidesz won the 2018 Hungarian elections by a landslide, securing $49.3 \%$ of the vote and 133 of the 199 seats in the Hungarian parliament. In doing so they have managed to decimate the opposition and make Hungary dangerously close to a single-party state. They have managed to do this through creating a state monopoly on the media, especially in rural areas, and through large-scale anti-migrant and anti-Soros propaganda campaigns deployed nationally. Hours after their election win Fidesz announced plans to enact a "Stop Soros" bill, a campaign clearly intended to crack down on NGOs, critical intelligentsia, and other opponents to Fidesz's rule. Prior to the elections, Fidesz announced that they had created a list of 2000 "Soros agents", of which 200 names were published in the pro-Fidesz Figyelö magazine immediately following the April 2018 elections. On this list were people working for various humanitarian NGOs in Hungary and academics at CEU in Budapest. In June of 2018, the "Stop Soros" bill was approved in parliament, effectively criminalizing any act or organization, which helps refugees in Hungary. More recently, kindergartens are to teach "Christian culture" and "strengthen national identity," beginning in September of 2018 (Dull 2018). Fidesz has now outlawed gender studies programs in Hungary, and it is leading a campaign to convince women to birth more children.

The landscape of Hungarian nationalism is quite broad. However, it can be divided into three main groups of organizations: political movements, social movement organizations, and fringe movements. The political movement has been previously described here; it is constituted by the various political parties that can be situated on the far right, namely Jobbik, Fidesz, and the newly founded Our Homeland movement. The second group reunites those larger organizations that may have a political affiliation, but do not take part in politics directly; this group includes organizations like the Hungarian Guard, the newly formed National Legion, and the Sixty-Four Counties Youth Movement. The last group includes the fringe organizations with smaller membership numbers, including chapters of international skinhead organizations. Several of the more prominent far-right organizations are presented here as examples of the different forms of nostalgic nationalism; all organizations presented below can be considered under the second category of groups, as they are not directly in the political sphere and are the mainstream organizations of the Hungarian far-right.

In Hungary, a prominent symbol used by the far-right is the Árpád Flag, originally the flag of the first Hungarian dynasty, which consists of alternating red and white horizontal stripes. Revived by the national socialist Arrow Cross Movement (Nyilaskeresztes Párt-Hungarista Mozgalom) in the 1930s, the flag was banned by the Soviets less than two decades later. After the end of Soviet influence in Hungary, however, the flag witnessed a rebirth in the Hungarian nationalist movement. Other noticeable symbols of Hungarian nationalist movement supporters are the wearing of a tarsoly, the use of ancient Hungarian runic writing, and the image of turul (a mythical ancient Magyar bird). It is worth noting that other important national symbols to the Hungarian people, which originate in the more recent history have not 
been adopted by the Hungarian nationalist movement. For instance, the raven with a ring in its beak as a sign of King Matthias Corvinus (r. 1458-1490), one of the most highly regarded Hungarian kings, has not been appropriated.

As highlighted above, one of the most prominent attitudes characterizing Hungarian nationalist movements is irredentism and concern around the Treaty of Trianon, presenting a nostalgia for a time when all ethnic Hungarians were part of the same state. Self-identifying as a radical youth nationalist movement, the SixtyFour Counties Youth Movement (Hatvannégy Vármegye Ifjúsági Mozgalom, HVIM) was founded on 21 April 2001 by László Toroczkai. The organization is decidedly irredentist, their name being an homage to the sixty-four counties constituting the Kingdom of Hungary, as part of Austria-Hungary dual monarchy. HVIM have their main seat in Szeged, which lies in Csongrád county, as the organization believes this area to be the center of Hungary. The Csongrád county, which lies in southern Hungary, is believed to be the site of the original Blood Oath, which according to legend was the official pact between the seven Magyar tribes. This is also the birthplace of Sándor Rózsa, a highwayman and outlaw who led his own company into battle in the 1848 Hungarian Revolution. HVIM's symbolism and identity are obvious, both from their online presence and their name.

The Outlaw Army (Betyársereg), which was formed in 2008, have the somewhat threatening motto of "Don't hurt Hungarians, or else!" (Ne bánstd a magyart, mert pórul jársz!). The leader of the Outlaw Army, Zsolt Tyirityán, is one of the most well-known figures in the Hungarian far-right movement. The organization asserts that they are a loose alliance of self-organized clans, which abide to the traditions of Eurasian civilizations. They profess to disregard the laws of the state in favor of following the ancient laws of the Hungarian plains (puszta); they compare themselves to the outlaws of the past, arguing that they have been forced to act outside of the law by contemporary political and state structures. Their logo is a skull wearing the same hat, and in in the same orientation, as the well-known image of the famous Hungarian outlaw Sándor Rózsa. The Outlaw Army has close ties to several of the other prominent far-right organizations in Hungary, including the new Our Homeland party (for example, Plankog 2019).

Looking back to the twentieth century is the New Hungarian Guard Movement (Új Magyar Gárda Mozgalom), formed in 2009 after the original Hungarian Guard Movement was dissolved, 3-weeks prior. The initial Hungarian Guard Movement was founded in 2007 with 56 members, a number chosen to commemorate the 1956 revolution (LeBoer 2008). The new organization is now split into local chapters, perhaps strategically so, in order to avoid a repeated dissolution. According to the New Hungarian Guard's old website which has now been removed, the organization's tenets include trust in God, and their actions must abide by the ancient rights of freedom, and ancient traditions. Their main goal is to protect the Hungarian state, and the interests of the Hungarian nation, but it is unclear as to how they attempt to achieve this. The organization has also revitalized symbols of the national socialist Arrow Cross regime, using the red-and-white striped Árpád flag in their emblem and wearing a uniform consisting of black boots, black pants, black military 
waistcoats, white shirts, and a black cap emblazoned with the Árpád stripes (Holdsworth and Kondor 2017).

Finally, and perhaps most puzzling in terms of identity, is the Hungarian Defense Movement (Magyar Önvédelmi Mozgalom). The organization was formed in October of 2014 after the dissolution of the organization For a Better Future Hungarian Self-Defense (Szebb Jövöért Magyar Önvédelem), originally created after the disbanding of the Hungarian Guard discussed above. Outwardly, the Hungarian Defense Movement promotes an image of a helpful family- and community-oriented organization, which seeks to protect the Hungarian people, organizing food and clothing drives, depicting families along with children on their Facebook page, and organizing family-friendly events. The Hungarian Defense Movement has one of the largest support bases in the Hungarian nationalist movement with over 5500 supporters on Facebook. The organization regularly patrols the streets in areas with high concentrations of Roma and are openly anti-Roma. Among the organizations in the Hungarian nationalist movement, the Hungarian Defense Movement has the least obvious representations of nostalgic nationalism. In order to further explore these ideas in an organization, which outwardly does not show any obvious identity of nostalgic nationalism, interviews with its members are analyzed in the following section.

Presenting a nationalist identity that is new to the Hungarian nationalist movement is the Identitarian movement, which has also appeared in Hungary with two separate and unrelated organizations. The short-lived Identitesz was created in September 2015 at a University in Budapest, originally titled the Conservative Student Society. The organization was led by László Balázs and claimed to build a "new right". Identitesz has since dissolved, after announcing its intent to become a political party. It ultimately joined forces with the Outlaw Army. On 8 July 2017, the two organizations formed a coalition movement called Strength and Devotion (Erö és Elszántság), at which time Balázs resigned as the leader of Identitesz.

Identitesz was often confused with the Hungarian branch of the Generation Identity movement (Identitás Generáció) (for a wider European analysis of Generation Identity, see Nissen, Chap. 6 in this volume). The Hungarian Generation Identity was formed in 2014, and seemingly in 2017 had about 100 members (Kulcsár and Halász 2017). Along a different line from the more traditional nationalist organizations in Hungary, Generation Identity deem important to protect both the European and Hungarian identity, namely from the threats of migration and Islam. They claim to not have any issues with any one particular group of people, Muslims included, but to be against the "Islamization" of Europe. They are concerned with the supposed replacement of European peoples by migrants and refugees and subscribe to ethnopluralist views. Their actions around Budapest have included displaying large banners in public areas, with such slogans as "Islamization kills!" (Dezse 2017) and commemorating the Siege of Buda on 2 September 1686. The siege originally marked a defeat of the Ottoman forces, but now is framed to represent the freeing of Hungarians from Islam. This organization epitomizes a particularly curious case for studying Hungarian national identity. They are, indeed, a part of a much larger network whereby all subscribe to the ideals of ethnopluralism 
and are against Islamization. However, they are also focused on specifically Hungarian issues, among them the idea of bringing back Hungary's "glorious days". At a closer look of their online activities, some of these issues become clearer. For instance, its leader Ábel Bódi complained that the main issue in contemporary European societies is that the youth no longer have a true identity; and argued that youth should be proud of their national identity and heritage (Sellner 2017). While referring to the "Hungarian golden age" of some 150 years ago, the organization is at the same time looking toward the future, proclaiming its goal to "making Hungary more European" (Sellner 2017). Bódi has been open about his Austrian-Hungarian ancestry and his desire to recreate the union of the two countries. Of all the organizations, Generation Identity is the only one to present a distinctive desire to recreate the past.

Apparent in the ideology of each organizations is the idea that they are the protectors of the Hungarian people and the country borders; that they belong to a retrogressive mobilization that will bring Hungary back to the time they see as the country's "golden age". HVIM seeks to restore the borders of Greater Hungary, the Hungarian Guard looks to the twentieth century, the Outlaw Army venerates the time of outlaws, and Generation Identity looks to the time of the Austro-Hungarian dual monarchy, and the defeat of Otto-man/Muslim forces.

\subsection{Discussions with Hungarian Nationalists}

Four distinct themes emerged when discussing questions of Hungarian national identity and nostalgia. First, the importance of Magyar ancestors and the conquering period of the Carpathian Basin. Second, the importance of Christianity and Hungarians as a Christian people. Third, the nineteenth and twentieth centuries and the "golden age" of the Hungarian intelligentsia. Finally, the idea of Hungarians as victims, both in terms of the effects of the Trianon Treaty, and in the sense that the history of Hungarian people was in some way stolen, leaving a need to regain and rebuild Hungarian national identity.

Interview participants frequently alluded to the culture of the ancient Hungarians. One respondent discussed learning about the Conquering Period in school, and even remembered the feelings of national pride they had as a child:

In school we learned about the ancient Hungarians, the ancestors, like Lehel, Emese, Attila, and Árpád, and I was filled with pride that we have more than a one-thousand-year-old history, and I have these types of ancestors. (Respondent 1)

This is significant when considering the new kindergarten curriculum instituted by the Fidesz government, in which they aim to "strengthen national identity" (Dull 2018). Orbán's government has repeatedly emphasized control over the educational curriculum in Hungary, aiming to reform the education system and country in their nationalist and Christian image (McKenzie 2019). Another respondent, when discussing the aims of the organization stated that: 
...with us [the Hungarian Defense Movement] the emphasis is rather on bringing back the old Hungarian values and living by them. (Respondent 2)

What these values are remains unclear, as is whether these values would be those of the nomadic Magyars or the later Christian Medieval Hungarians.

There was a strong emphasis on Christian beliefs from all respondents, with one saying "God bless you" at the end of the interview (Respondent 2). One participant was particularly vocal in articulating the role of religion; this respondent, speaking about the organization, said they "believe in the unity of the Holy Crown" (Respondent 1) and "in Christian teachings" (Respondent 1). When pressed, they further stressed the importance of Christian values to the organization:

Yes, well, for example, umm, coexistence with Christian beliefs and umm, teachings. And whether this is going to church, or the compliance with the Hungarian Believe in One motto $\left(\right.$ Magyar Hiszekegy $\left.{ }^{3}\right)$. We take a vow each year before the Holy Crown in order to renew our oath, and live by this oath as much as possible. (Respondent 1).

This notwithstanding, at times it became apparent that even the participant was struggling to reconcile idealization of the nomadic pagan Magyars and Christianity. Respondents would not deny the Hungarian peoples' pagan Magyar past, but would find ways to explain how this past suits a European Christian image:

Well, if we really look into our history, Hungarians have always, always been a spiritually Christian people, even though they did not technically belong to the Catholic Church. (Respondent 1)

This suggests a fascinating blurring of national and historical identity, blending the two separate periods of the nation's history to create an imagined nostalgia.

One participant spoke about Hungarians as a nation who contributed much to the world and the furthering of society. They were proud of their country, which they openly discussed:

We know that we're a nation who left a mark on the world, multiple times, even the world wars, from inventions to grammar, our language, our talents. (Respondent 3 )

This participant rejected the idea that the Hungarians were conquered and defeated throughout history:

What they taught me way back in elementary school, that they just defeated us everywhere, we lost everywhere, and, and that we were slaves, or I don't know what, that is truly stupid. (Respondent 3)

They unfortunately did not clarify which particular instances were incorrectly taught in school. This idea connects with the process of national identity formation and recreation that is seemingly happening among those in the Hungarian far-right, potentially obfuscating history in order for their nation to not seem weak. Despite this, all respondents spoke, at times, of the Hungarian people and the country of

\footnotetext{
${ }^{3}$ Magyar Hiszekegy is a poem written in 1920 by Szeréna Sziklay, wife of General Elemér PappVáry, for a competition run by an anti-Trianon movement: "I believe in one God, I believe in one home, I believe in God's eternal truth, I believe in Hungary's resurrection. Amen."
} 
Hungary as victims, with particular mentioned made of the injustice of the treaty of Trianon. One respondent emphasized how unfairly the Hungarian people were treated:

Not one nation in the world has had something done to them like what was done to the Hungarians with Trianon. (Respondent 2)

Another set Trianon in the context of Hungary as a holy country:

...for the country of the Holy Crown to be together again, which they separated during Trianon. (Respondent 1)

Other participants spoke of the victimization of Hungarian people in terms of national identity, with one noting:

.... and then there's our national identity, our past, our history, which they took from us.

(Respondent 3)

And

...this Hungarian national identity needs to be preserved, it must be rebuilt. (Respondent 3)

It seems as though this perceived victimization serves to justify the views and attitudes held by far-right supporters.

Results of these interviews demonstrates that there are not clear ideological and identity-based lines between the organizations in the Hungarian far-right movement. Indeed, members of one organization can cover a spectrum of attitudes and beliefs. This, however, is likely more apparent among members of the Hungarian Defense Movement as the organization is not as strongly ideologically-motivated as others. Another point that becomes clear is that most organizations in the mainstream Hungarian far-right movement embody nostalgic nationalism to some degree, with it often being central to the ideology of the organization. These interviews have also demonstrated a mixture between a nostalgia for the time of the ancient Magyars and the later Christian medieval Hungarian periods, which presents a perplexing formula for nationalist identity as well as an explicit desire to reclaim that identity.

\subsection{Conclusions: National Identity in Conflict}

This chapter explores several concepts surrounding the nostalgia connected to nationalism in Hungary. One of the main periods of Hungarian history used symbolically by traditional Hungarian nationalist organizations is the time of the Hungarian conquest of the Carpathian Basin, leading to a pan-Turanism that seeks identity outside Europe. No less influential is the period of conversion to Christianity, with many in the Hungarian far-right promoting the idea of a Christian Europe, and a Christian Hungary. Greater than both, however, is the single most important historical event to the Hungarian nationalist movement: the Treaty of Trianon. 
Taking a closer look at the attitudes and beliefs circulating within the Hungarian nationalist movement, and at the history of the country, reveals a few paradoxes. First, the idea of a "pure" Hungarian people cannot exist in a country that has witnessed so many and varied waves of de- and re-population. Second, the conflict between the culture and ancestry of pagan Magyars cannot easily be reconciled with the idea of Hungarians as a Christian people. Indeed, despite the protestations of interview respondents, it is clear that elevating both is an exercise in cognitive dissonance. While this is not uncommon amongst nationalist groups elsewhere - for example, in Italy, Scandinavia, and Russia (see: Laurelle 2008; François and Godwin 2008) - its prominence in the discourse of Hungarian groups is, perhaps, somewhat unusual.

While the results of a comparably small qualitative study prevent the drawing of unambiguous conclusions, the findings of analysis presented in this chapter suggest that Hungarian nationalist nostalgia is often complex, contested, and at odds with itself. Groups and individuals can construct their own national and historical identities by piecing together and blending ideas from several periods of their nation's history, creating compound identities that make the Hungarian far-right less a cohesive movement and more a mass of groups in temporary and fluctuating allegiance, willing to work with or against each other on an issue by issue basis. Further research is clearly necessary to explore these issues in more detail, and in particular to ascertain whether the findings of these interviews are replicated in respect of other groups. If this is the case, it may have clear implications for both existing scholarship, foregrounding the importance of imagination and nostalgia in shaping the ideology and outlook of far-right groups, and counter-extremism policy, highlighting the possibility for education, and greater historical literacy, to contest and challenge the drivers of engagement in far-right groups. However, the extent to which the Hungarian state - under the leadership of a far-right party - is willing to engage in such action remains to be seen.

\section{References}

Bartlett, J., Birdwell, J., Krekó, P., Benfield, J., \& Győri, G. (2012). Populism in Europe: Hungary. London: Demos.

Breuilly, J. (1993). Nationalism and the state. Manchester: Manchester University Press.

Dekker, H., Malová, D., \& Hoogendoorn, S. (2003). Nationalism and its explanations. Political Psychology, 24(2), 345-376.

Dezse, B. (2017, October 5). Hatalmas molinóval tiltakozott az iszlamizáció ellen a budapesti Identitás Generáció. Pesti Srácok. https://pestisracok.hu/hatalmas-molinoval-tiltakozott-aziszlamizacio-ellen-budapesti-identitas-generacio/. Accessed 16 Oct 2018.

Dull, S. (2018, August 6). Elöírták a nemzeti nevelést az óvodákban. Index. https://index.hu/belfold/2018/08/06/eloirtak_a_nemzeti_nevelest_az_ovodakban/. Accessed 6 Aug 2018.

ECHO TV. (2018). Pártként folytatja a Mi Hazánk Mozgalom - Toroczkai László - ECHO TV. https://www.youtube.com/watch?v=aSLWnByXydY. Accessed 5 July 2018. 
Edelman, M. (1985). The symbolic use of politics. Chicago: University of Illinois Press.

Elgenius, G. (2011). Symbols of nations and nationalism: Celebrating nationhood. New York: Palgrave Macmillan.

Engel, P. (2001). The realm of St. Stephen: A history of medieval Hungary 895-1526. New York: I.B. Tauris.

Fekete, L. (2016). Hungary: Power, punishment and the 'Christian-national ideal'. Race and Class, 57(4), 39-53.

Firth, R. (1973). Symbols: Public and private. London: George Allen \& Unwin.

François, S., \& Godwin, A. (2008). The Euro-Pagan scene: Between paganism and radical right. Journal for the Study of Radicalism, 1(2), 35-54.

Gottlieb, J. V., \& Linehan, T. P. (Eds.). (2003). Culture of fascism: Visions of the far right in Britain. London: IB Tauris.

Goulding, C. (1999). Heritage, nostalgia, and the "grey" consumer. Journal of Marketing Practice: Applied Marketing Science, 5(6), 177-199.

Hajdú, T., \& Nagy, Z. L. (1990). Revolution, counterrevolution, consolidation. In P. F. Sugar, P. Hanák, \& T. Frank (Eds.), A history of Hungary (pp. 295-318). London: IB Tauris.

Heijmans, P. (2019, March 20). EPP suspends Hungary's far-right Fidesz Party. Al Jazeera. https:// www.aljazeera.com/news/2019/03/epp-suspends-hungary-fidesz-party-190320193105401. html? fbclid=IwAR0CxN_cFntCgNphdPEGk2moKSOPOCtYdWmsq946UNtnpoW0IxZj8MZWuoY. Accessed 16 Aug 2019.

Holdsworth, J., \& Kondor, K. (2017). Understanding violence and the Hungarian far-right. In A. Kallis, S. Zeiger, \& B. Öztürk (Eds.), Violent radicalization and far-right extremism in Europe (pp. 173-216). Ankara: SETA.

HVIM. (2018, July 10). Hogyan állitotta meg HVIM a vonaglást?. Hatvannégy Vármegze Ifjúsági Mozgalom. https://www.hvim.hu/single-post/2018/07/10/Hogyan-allitotta-meg-aHVIM. Accessed 18 Oct 2018.

Juhász, A. (2010). The political career of the word ‘Gypsy crime' [A ‘cigánybünözés' szó poli-tikai karrierje]. The Political Capital Institute. http://www.politicalcapital.hu/blog/?p=1937578. Accessed 20 July 2017.

Kulcsár, R., \& Halász, J. (2017, September 3). Európa, mármint fehér Európa. 444. https://444. hu/2017/09/03/europa-marmint-feher-europa. Accessed 16 Oct 2018.

Kyriazi, A. (2015). Ultranationalist discourses of exclusion: A comparison between the Hungarian Jobbik and the Greek Golden Dawn. Journal of Ethnic and Migration Studies, 42, 2528-2547.

Laurelle, M. (2008). Alternative identity, alternative religion? Neo-paganism and the Aryan myth in contemporary Russia. Nations and Nationalism, 14(2), 283-301.

LeBoer, A. (2008). Marching back to the future: Magyar Garda and the resurgence of the right in Hungary. Dissent, 55(2), 34-38.

Loch, D., \& Norocel, O. C. (2015). The populist radical right in Europe: A xenophobic voice in the global economic crisis. In H.-J. Trenz, C. Ruzza, \& V. Guiraudon (Eds.), Europe's pro-longed crisis: The making and unmaking of a political union (pp. 251-269). Basingstoke: Palgrave Macmillan.

Mach, Z. (1993). Symbols, conflict, and identity: Essays in political anthropology. Albany: State University of New York Press.

McKenzie, S. (2019, February 6). Why Hungary's state-sponsored schoolbooks have teachers worried. $C N N$. https://www.cnn.com/2019/02/01/europe/hungary-education-orban-textbooks-intl/ index.html. Accessed 16 Aug 2019.

Molnár, M. (2001). A concise history of Hungary. Cambridge: Cambridge University.

Mudde, C. (2015, August 10). Is Hungary run by the radical right? The Washington Post. https:// www.washingtonpost.com/news/monkey-cage/wp/2015/08/10/is-hungary-run-by-the-radicalright/?utm_term=.2416548fcb2c. Accessed 7 July 2018.

Payne, S. (1980). Fascism: Comparison and definition. Madison: University of Wisconsin Press. 
Plankog. (2019, May 8). Visszatérnek a vonulások Magyarországra: Mi Hazánk-Betyársereg-menet jön a „,cigányterror” ellen. 444. https://444.hu/2019/05/08/visszaternek-a-vonulasok-magyarorszagra-mi-hazank-betyarsereg-menet-jon-a-ciganyterror-ellen. Accessed 16 Aug 2019.

Schatz, R. T., \& Lavine, H. (2007). Waving the flag: National symbolism, social identity, and political engagement. Political Psychology, 28(3), 329-355.

Sellner, M. (2017, October 22). Generation Identity Hungary-Ábel Bódi. YouTube. https://www. youtube.com/watch?v=SuuVNsYxokw\&feature=youtu.be\&a=. Accessed 16 Oct 2018.

Simon, A. L. (1998). Made in Hungary. Safety Harbor: Simon Publications.

Smith, A. D. (1995). The dark side of nationalism: The revival of nationalism in late nineteenth century Europe. In L. Cheles, R. Fergwon, \& M. Vaughan (Eds.), The far right in western and eastern Europe (2nd ed., pp. 13-19). London: Longman.

Smith, A. D. (2001). Nationalism: Theory, ideology, history. Cambridge: Polity Press.

Thorpe, N. (2016, November 15). Is Hungary's Jobbik leader really ditching far-right past? BBC News. https://www.bbc.com/news/world-europe-37976687. Accessed 7 July 2018.

Wootson, C. R. (2018, June 23). 'Billy Elliot' shows canceled in Hungary amid cries that musical is 'gay propaganda'. The Washington Post. https://www.washingtonpost.com/news/worldviews/ $\mathrm{wp} / 2018 / 06 / 23 /$ billy-elliot-shows-canceled-in-hungary-amid-cries-musical-is-promotinghomosexuality/?noredirect=on\&utm_term=.6bc3a7c3a0f7. Accessed 18 Oct 2018.

Open Access This chapter is licensed under the terms of the Creative Commons Attribution 4.0 International License (http://creativecommons.org/licenses/by/4.0/), which permits use, sharing, adaptation, distribution and reproduction in any medium or format, as long as you give appropriate credit to the original author(s) and the source, provide a link to the Creative Commons license and indicate if changes were made.

The images or other third party material in this chapter are included in the chapter's Creative Commons license, unless indicated otherwise in a credit line to the material. If material is not included in the chapter's Creative Commons license and your intended use is not permitted by statutory regulation or exceeds the permitted use, you will need to obtain permission directly from the copyright holder.

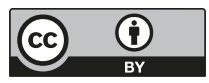

